\title{
SYNTHESIS OF MESOPOROUS SILICA-ALUMINA FROM LAPINDO MUD AS A SUPPORT OF Ni AND Mo METALS CATALYSTS FOR HYDROCRACKING OF PYROLYZED $\alpha$ - CELLULOSE
}

\author{
Hesty Kusumastuti ${ }^{1}$, Wega Trisunaryanti ${ }^{1}$, Iip Izul Falah ${ }^{1}$ \\ and Muhammad Fajar Marsuki ${ }^{1}$ \\ ${ }^{1}$ Departement of Chemistry, Universitas Gadjah Mada, Yogyakarta, Indonesia \\ *E-mail: wegats@ugm.ac.id
}

\begin{abstract}
Synthesis of mesoporous silica-alumina (MSA) as a support of $\mathrm{Ni}$, Mo, NiMo, and MoNi catalysts for hydrocracking of pyrolyzed $\alpha$-cellulose had been carried out. The MSA was synthesized using $\mathrm{SiO}_{2}$ and $\mathrm{Al}_{2} \mathrm{O}_{3}$ from Lapindo mud and catfish bone gelatin as a template by hydrothermal method. The MSA was characterized by FTIR, XRD, AAS, SAA and TEM. The acidity value of MSA was determined gravimetrically by pyridine vapor adsorption. The liquid products obtained from hydrocracking of pyrolyzed $\alpha$-cellulose were analyzed by GC-MS. The result shows that the MSA had Si/Al ratio, BET specific surface area, acidity value, BJH desorption pore diameter and pore volume of $5.65,212.29 \mathrm{~m}^{2} / \mathrm{g}, 13.56 \mathrm{mmol} / \mathrm{g}, 20.05 \mathrm{~nm}$ and $1.29 \mathrm{~cm}^{3} / \mathrm{g}$, respectively. The highest conversion of liquid product was obtained in hydrocracking of pyrolyzed $\alpha$-cellulose using the NiMo/MSA and MoNi/MSA catalysts. The NiMo/MSA and MoNi/MSA catalysts produced a liquid fraction of $85.51 \mathrm{wt} . \%$ and 85.29 wt.\%, respectively.
\end{abstract}

Keywords: mesoporous silica-alumina, gelatin, catalyst, hydrocracking, $\alpha$-cellulose.

@ R RASĀYAN. All rights reserved

\section{INTRODUCTION}

Biomass is a potential material that can be used as a new valuable chemicals source. The Biomass has several benefits such as renewable, generating relatively low $\mathrm{CO}_{2}$ and having an insignificant amount of sulfur $^{1,2}$. Biomass is mainly composed of cellulose, hemicellulose, lignin and slight amounts of other organic compounds ${ }^{2}$. Cellulose is the most important component because it has the largest portion of biomass $^{3}$. The pyrolysis process can convert the biomass into bio-oils that have a potential to be used as alternative fuels and chemicals production. Some chemicals with high demand such as methanol, acetic acid, acetone and phenol can be obtained from bio-oil ${ }^{4-6}$. However, bio-oils obtained from pyrolyzed cellulose are known to have acidic character, condensed, low thermal stability and contain many oxygenated compounds ${ }^{2}$, therefore it is necessary to improve the quality of bio-oil from pyrolyzed cellulose by hydrocracking process.

The hydrocracking process requires a catalyst which corresponds to the character of the feedstock. Different types of transition metals have been widely studied as hydrocracking reaction catalysts in the previous studies $^{7-13}$. The hydrodeoxygenation and hydrocracking process of solvolyses lignocellulose using NiMo catalysts results in higher liquid products conversion than that of $\mathrm{Ni}$ catalysts $^{14}$. The use of NiMo catalyst gives a higher catalyst acidity than Ni and Mo catalysts ${ }^{15}$. However, the use of metal as catalyst directly can cause the occurrence of sintering and agglomeration. These problems can be solved by using a porous material that has a large surface area as a support for the transition metals.

Mesoporous material such as zeolite is widely used as a catalyst support due to its great properties such as high porosity, large surface area, high chemical stability and optimum acidity ${ }^{16}$. The synthesis of mesoporous silica-alumina (MSA) requires a template for directing mesoporous formation. The use of biopolymer as a template attracts the researchers due to its properties such as availability in the wide 
variety of sources, its complex structure, nontoxic and easy removal ${ }^{17}$. Gelatin is a biopolymer derived from collagen and it is a good material as a mesoporous regulating template agent due to its solubility in water, abundantly and low $\operatorname{cost}^{18}$. The synthesis of mesoporous silica using bovine bone gelatin as a template had been successfully performed ${ }^{18-20}$. However, research on the use of gelatin from catfish bone as a template for synthesis of MSA is still rare. In present work, the synthesis of MSA was carried out using materials derived from Lapindo mud and gelatin from catfish bone as a mesoporous regulating template agent. The MSA was used as a support material of $\mathrm{Ni}$, Mo, NiMo and MoNi catalysts. The catalysts activity was evaluated for hydrocracking of pyrolyzed $\alpha$-cellulose.

\title{
Detection Method
}

\section{EXPERIMENTAL}

The chemical composition of Lapindo mud was analyzed and determined using X-Ray Fluorescence (Olympus Handheld XRF Analyzer Delta Premium DP-2000) with mining mode analysis. The functional groups of all sample were determined using Fourier Transform Infrared spectrometer (FTIR, Shimadzu Prestige-21) equipped with data station in the range of $400-400 \mathrm{~cm}^{-1}$ with a $\mathrm{KBr}$ disc technique. Sodium Dodecyl Sulphate-Poly Acrylamide Gel Electrophoresis (SDS-PAGE, ATTO PAGERUN ELMER 3110) was used to determine the molecular weight distribution range of the gelatin. The surface parameters (surface area, pore volume, and pore diameter) of the samples were analyzed using Surface Area Analyzer (SAA, Quantachrome NovaWin Series). The sample was firstly degassed at $300 \square$ for $3 \mathrm{~h}$. The analysis was based on physical adsorption of $\mathrm{N}_{2}$ gas at a batch temperature of $77.3 \mathrm{~K}$ and outgas temperature of $80 \square$. The equilibrium time for both physical adsorption and desorption of $\mathrm{N}_{2}$ gas was $60 \mathrm{sec}$ for each measurement point with pressure tolerance of 0.100/0.100 (ads/des). X-Ray Diffraction (XRD, Rigaku MiniFlex 600) was used to observe the crystallinity of the MSA. The pore images were taken using Transmission Electron Microscope (TEM, JEOL JEM-1400) at $120 \mathrm{kV}$ accelerating voltage. The amount of metals content of all samples was determined using Atomic Absorption Spectrophotometer (AAS, Perkin Elmer 3110). The liquid products obtained from hydrocracking of waste lubricant were analyzed using gas chromatography-mass spectrometry (GC-MS, Shimadzu QP2010S) with a column length of 30 $\mathrm{m}$, the diameter of $0.25 \mathrm{~mm}$, the thickness of $0.25 \mu \mathrm{m}$ at a temperature of $60-310 \square$ using Helium gas as a carrier gas and an acceleration voltage of $70 \mathrm{Ev}$.

\begin{abstract}
Material
Catfish bone was collected from Tegalrejo Village, Central Java, Indonesia and the Lapindo mud was obtained from Sidoarjo Regency, East Java, Indonesia. Hydrochloric acid $(\mathrm{HCl})$ was purchased from Mallinckrodt. Sodium hydroxide $(\mathrm{NaOH})$, acetic acid $\left(\mathrm{CH}_{3} \mathrm{COOH}\right)$, nickel (II) chloride hexahydrate $\left(\mathrm{NiCl}_{2} \cdot 6 \mathrm{H}_{2} \mathrm{O}\right)$ and ammonium heptamolybdate tetrahydrate $\left(\left(\mathrm{NH}_{4}\right)_{6} \mathrm{Mo}_{7} \mathrm{O}_{24} \cdot 4 \mathrm{H}_{2} \mathrm{O}\right)$ were purchased from Merck. All of the reagents used in this work were analytical grade and they were used without further purification.
\end{abstract}

\section{General Procedure \\ Synthesis of Mesoporous Silica-Alumina}

Silica $\left(\mathrm{SiO}_{2}\right)$ and alumina $\left(\mathrm{Al}_{2} \mathrm{O}_{3}\right)$ was extracted from Lapindo mud using $6 \mathrm{M} \mathrm{NaOH}$ and $6 \mathrm{M} \mathrm{HCl}$ solution at $90 \square$, respectively. Catfish bone was prepared by soaking it in $0.1 \mathrm{M} \mathrm{NaOH}$ solution for $24 \mathrm{~h}$ and then $1.5 \mathrm{M} \mathrm{HCl}$ solution for $1 \mathrm{~h}$. Gelatin was extracted from the catfish bone using aqua bidest at $70 \square$. The extracted catfish bone gelatin was dissolved in aqua bidest at $40 \square$ and it was stirred for 30 min. The gelatin solution was mixed with alumina and the mixture was stirred for $30 \mathrm{~min}$. On the other glass container, silica was dissolved in aqua bidest and it was stirred for $30 \mathrm{~min}$. The silica solution was then mixed with $1 \mathrm{M} \mathrm{CH}_{3} \mathrm{COOH}$ solution until reaching $\mathrm{pH}$ 4. The acidic silica solution ( $\mathrm{pH} 4$ ) was inserted into the mixture of gelatin-alumina and the mixture of gelatin-alumina-silica was then stirred for $24 \mathrm{~h}$ at room temperature. The formed gel solution was transferred into an autoclave and it was hydrothermally treated at $100 \square$ for $24 \mathrm{~h}$. The solid obtained from hydrothermal treatment was filtered and it was washed with aqua bidest. The solid was then dried at $50 \square$ over a night. Finally, the solid was 
calcined at $550 \square$ for $4 \mathrm{~h}$ for removing of gelatin and the resulting solid was the MSA. The MSA was analyzed FTIR spectrometer, AAS, TEM, SAA and acidity test (pyridine adsorption).

\section{Preparation of Catalysts}

Nickel (Ni) and molybdenum (Mo) metals were impregnated onto the MSA by wet impregnation method using $\mathrm{NiCl}_{2} \cdot 6 \mathrm{H}_{2} \mathrm{O}$ and $\left(\mathrm{NH}_{4}\right)_{6} \mathrm{Mo}_{7} \mathrm{O}_{24} \cdot 4 \mathrm{H}_{2} \mathrm{O}$ salt solution. The mixture of MSA-salt solution was stirred for $24 \mathrm{~h}$ at room temperature and it was then dried at $70 \square$ for over a night. The catalyst was flowed by $\mathrm{N}_{2}$ gas and it was calcined at $500 \square$ for $3 \mathrm{~h}$. The catalyst was then flowed by $\mathrm{H}_{2}$ gas and it was heated at $450 \square$ for $3 \mathrm{~h}$. The Mo metal was impregnated onto the MSA followed by the Ni metal to produce $\mathrm{NiMo} / \mathrm{MSA}$ catalyst and vice versa for MoNi/MSA catalyst. The catalysts were characterized by AAS and acidity test (pyridine vapor adsorption).

\section{Acidity Test}

The acidity of the MSA and all catalysts were determined by flowing the pyridine vapor into the sample for $24 \mathrm{~h}$ at room temperature and vacuum condition. Their acidity value was calculated using the following equation:

$$
\text { Acidity Value }=\frac{\text { the weight of the sample after adsorption }- \text { the weight of the sample before adsorption }}{\text { the weight of the sample before adsorption } \times \text { Mr Pyridine }}
$$

\section{Hydrocracking of Pyrolyzed $\alpha$-Cellulose}

$\alpha$-cellulose was heated at $600 \square$ for $4 \mathrm{~h}$ under $\mathrm{N}_{2}$ gas stream to produce $\alpha$-cellulose pyrolysis oil. The liquid product obtained from pyrolysis of $\alpha$-cellulose was hydrocracked at $450 \square$ for $2 \mathrm{~h}$ in a reactor using catalysts synthesized in this study. The reactor used in the hydrocracking of pyrolyzed $\alpha$-cellulose was a semi-batch stainless steel (id: $4.5 \mathrm{~cm}$, od: $4.8 \mathrm{~cm}$, length: $30 \mathrm{~cm}$ ) where the $\alpha$-cellulose was firstly placed in the reactor before the hydrocracking process and the $\mathrm{N}_{2}$ gas flowed continuously into the reactor during the hydrocracking process. Catalyst/ $\alpha$-cellulose pyrolysis oil ratio was $1 / 30$. The liquid products obtained from hydrocracking of pyrolyzed $\alpha$-cellulose were analyzed by GC-MS.

\section{Characterization of Lapindo Mud}

\section{RESULTS AND DISCUSSION}

The XRF analysis result of Lapindo mud is presented in Table-1. The result shows that the Lapindo mud mainly consists of $\mathrm{Al}, \mathrm{Si}, \mathrm{Cl}, \mathrm{Ca}$ and $\mathrm{Fe}$. Moreover, the Lapindo mud also consists of others element such as $\mathrm{S}, \mathrm{K}, \mathrm{Ti}, \mathrm{V}, \mathrm{Cr}$ and $\mathrm{Mn}$ in slight quantities. It means that the Lapindo mud is a potential source of silica and alumina. However, the Lapindo mud cannot be used directly as a support material for metal catalyst because it consists of others metal which can affect the catalyst activity. Therefore, the silica and alumina must be extracted from the Lapindo mud. The previous study indicated that the purity of silica and alumina extracted from Lapindo mud was up to $100 \mathrm{wt} . \%$ and $89.69 \mathrm{wt} . \%$, respectively ${ }^{21}$

Table-1: Chemical Composition of Lapindo Mud

\begin{tabular}{c|c|c|c}
\hline Element & Quantity (wt.\%) & Element & Quantity (wt.\%) \\
\hline $\mathrm{Al}$ & 19.30 & $\mathrm{Ca}$ & 4.08 \\
\hline $\mathrm{Si}$ & 49.24 & $\mathrm{Ti}$ & 0.99 \\
\hline $\mathrm{S}$ & 1.31 & $\mathrm{~V}$ & 0.11 \\
\hline $\mathrm{Cl}$ & 8.17 & $\mathrm{Cr}$ & 0.12 \\
\hline $\mathrm{K}$ & 2.06 & $\mathrm{Mn}$ & 0.27 \\
\hline $\mathrm{Fe}$ & 14.06 & Others & 0.29 \\
\hline
\end{tabular}

\section{Characterization of Gelatin}

FTIR spectra of gelatin extracted from catfish bone are presented in Fig.-1(a). The changes in functional groups and secondary structure of gelatin were observed using FTIR spectroscopy ${ }^{22}$. Generally, FTIR 
spectra of gelatin should show five typical absorption bands for polypeptide called amide A, B and I-III. The gelatin extracted from catfish bone in this work had these five types of the amide. The amide A band which appeared at $3448 \mathrm{~cm}^{-1}$ indicates the stretching vibrations of the $\mathrm{NH}$ and $\mathrm{OH}$ groups ${ }^{19,23}$. The amide B band was observed at $2931 \mathrm{~cm}^{-1}$ and it corresponds to the asymmetric stretching vibration of $\mathrm{CH}_{2}{ }^{23,24}$. The FTIR spectra of gelatin exhibited the amide I band at $1635 \mathrm{~cm}^{-1}$. The amide I band represents $\mathrm{C}=\mathrm{O}$ stretching vibration (more than $80 \%$ ) of the amide group paired with in-plane NH bending (less than $20 \%$ ). The band is related to the loss of molecular structure of triple helix in consequence of the uncoupling of intermolecular cross-links and disorder of intramolecular bond of collagen ${ }^{19}$.

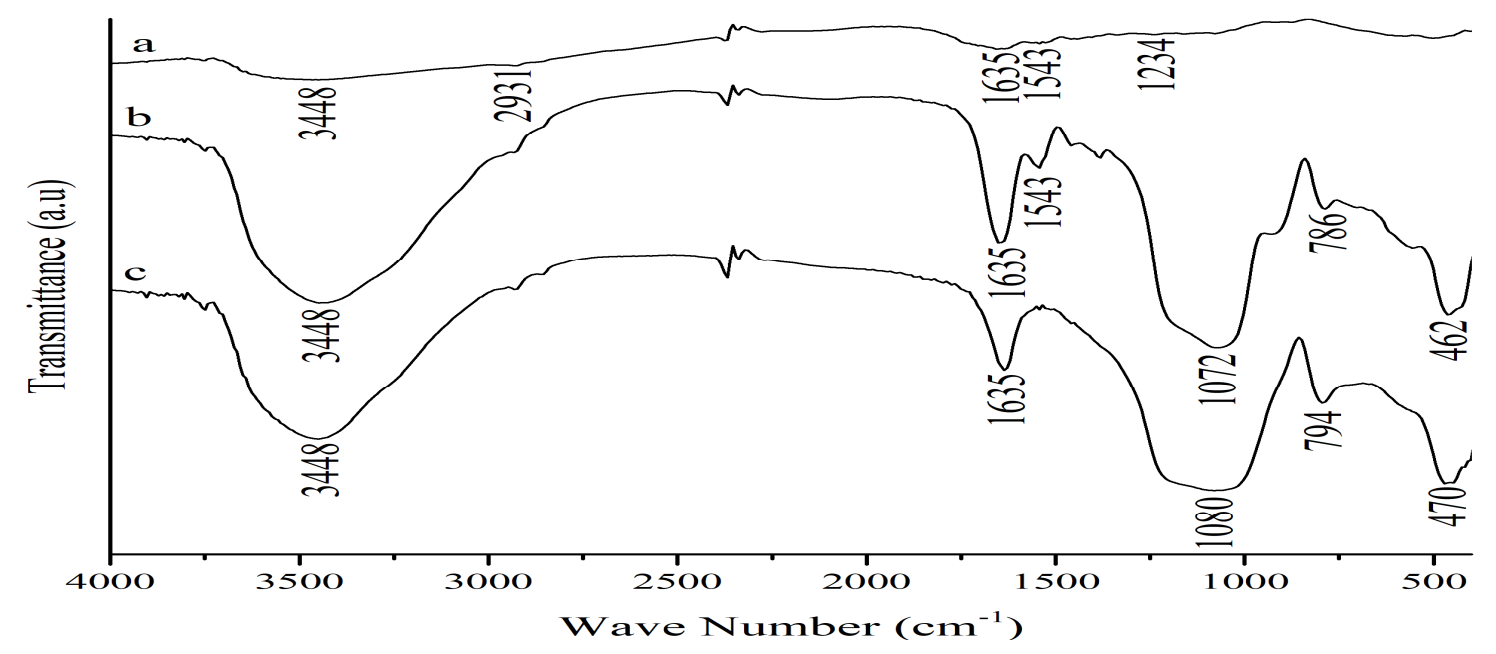

Fig.-1:FTIR Spectra of (a) catfish bone gelatin, (b) uncalcined MSA and (c) calcined MSA

The amide II band at $1543 \mathrm{~cm}^{-1}$ results from an out-of-phase combination of $\mathrm{CN}$ stretching and in-plane $\mathrm{NH}$ deformation modes of the peptide group ${ }^{24}$. The absorption band at $1234 \mathrm{~cm}^{-1}$ was amide III and it represents the combination peaks between $\mathrm{CN}$ stretching vibrations, $\mathrm{NH}$ deformation from amide linkages and $\mathrm{CH}_{2}$ wagging vibrations ${ }^{23}$. The amide III band is associated to the change of an $\alpha$-helical to a random twisted structure during the heating process and these changes are caused by the loss of triple helix form as a result of denaturation of collagen to gelatin ${ }^{22}$.

The yield of gelatin extracted from catfish bone is about $13.87 \mathrm{wt} . \%$. The acid treatment was carried out by removing some acid-soluble proteins, lipids and others undesired compound, disrupting the cross-links of collagen and swelling the bone ${ }^{23}$. The SDS-PAGE result shows that the gelatin had molecular weight distribution range of 10-291 $\mathrm{kDa}$. It means that the gelatin consists of $\alpha$ and $\beta$ chains and it can be used as a template for synthesis of MSA.

\section{Characterization of the MSA}

FTIR spectra of the MSA before and after calcination are presented in Fig.-1(b) and 1(c). The FTIR spectra of uncalcined MSA shows an absorption band in $1543 \mathrm{~cm}^{-1}$ which correspond to amide II band. This band indicates the formation of a gelatin-silica-alumina composite in the material framework. The calcination process was intended to remove gelatin from the MSA framework. The FTIR spectra of calcined MSA did not have the amide II band. It can be concluded that the calcination process is effective in removing of gelatin from the MSA framework ${ }^{20}$.

Figure-1(b) and (1(c) show an absorption band at $3448 \mathrm{~cm}^{-1}$ which corresponds to $\mathrm{OH}$ stretching vibration bound to $\mathrm{Si}$ or $\mathrm{Al}$, as well as the physisorption of $\mathrm{H}_{2} \mathrm{O}$ molecule on the MSA surface. The molecular vibration of absorbed $\mathrm{H}_{2} \mathrm{O}$ on the MSA is confirmed by the presence of absorption band at $1635 \mathrm{~cm}^{-1}$. This absorption band corresponds to the bending vibration of the $\mathrm{OH}$ groups, which can be attached to $\mathrm{Si}$ or $\mathrm{Al}$ atoms. The MSA structure is composed of the $\mathrm{TO}_{4}(\mathrm{~T}=\mathrm{Si}$ or $\mathrm{Al})$ tetrahedral framework. The 
absorption band at $1050-1150 \mathrm{~cm}^{-1}$ and $750-820 \mathrm{~cm}^{-1}$ correspond to the asymmetry and symmetry stretching vibration of T-O, respectively ${ }^{25}$. The absorption band at $450-470 \mathrm{~cm}^{-1}$ refers to the bending vibration of T-O-T ${ }^{26}$.

The absorption band corresponding to the vibration of T-O will generally shift to the higher wave number after calcination process. The calcination process can cause dehydration of the MSA surface. The dehydration process initiates the formation of non-framework $\mathrm{Al}$ ions, which have empty orbitals (Lewis acid site) ${ }^{27}$. The formation of non-framework $\mathrm{Al}$ ions causes decreasing of tetrahedral alumina number within the MSA framework and makes the absorption band to shift. A similar result was obtained in the previous study that showed a shifting of MCM-41 absorption band from $1074 \mathrm{~cm}^{-1}$ to $1094 \mathrm{~cm}^{-1}$ after calcination process $^{28}$.

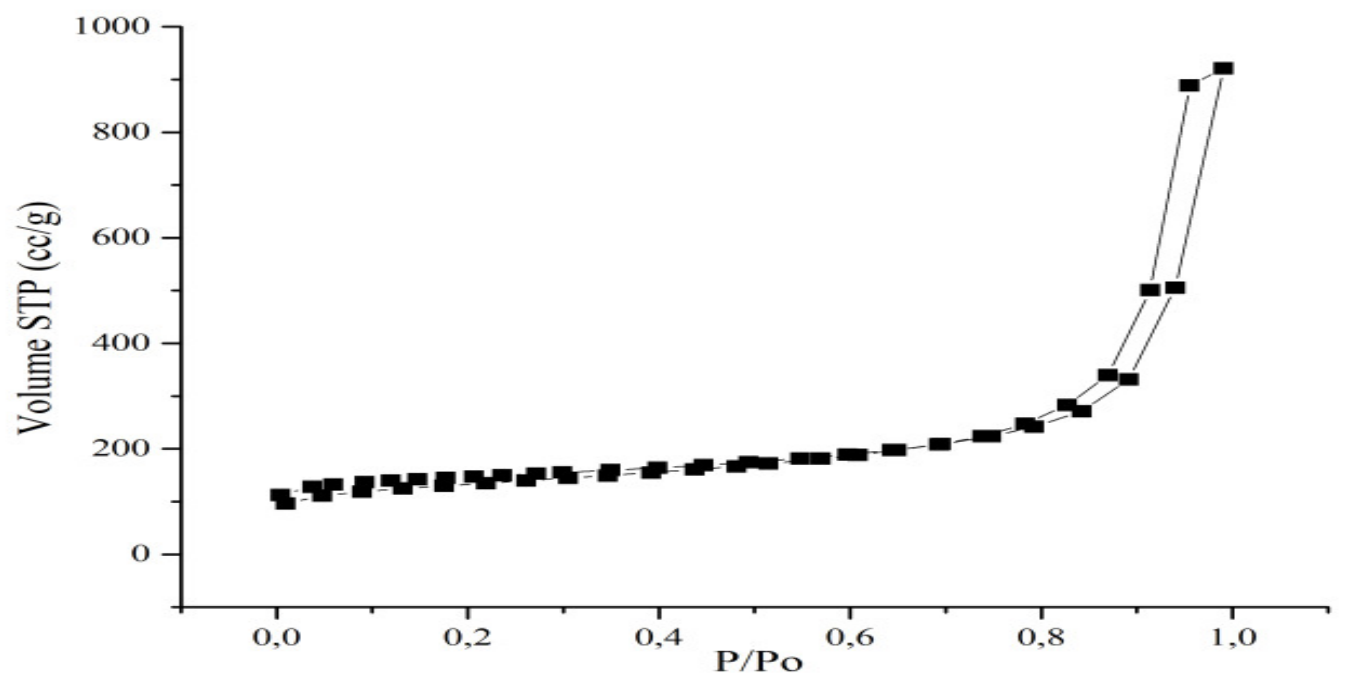

Fig.-2: Adsorption-desorption isotherm of the MSA

The adsorption and desorption isotherm of $\mathrm{N}_{2}$ gas on the MSA is illustrated in Fig.-2. The isotherm pattern of the MSA is indicated as adsorption of type I, which is typical of mesoporous material according to the IUPAC classification. The hysteresis type of the MSA can be classified as H1 type. The type H1 of the hysteresis loop is often attributed with porous materials which consist of agglomerates or compacts of approximately uniform spheres in a fairly regular arrangement and therefore, they have narrow distributions of pore size ${ }^{29}$. The MSA has BET surface area of $212.29 \mathrm{~m}^{2} / \mathrm{g}$, BJH desorption pore diameter of $20.05 \mathrm{~nm}$ and total pore volume of $1.29 \mathrm{~cm}^{3} / \mathrm{g}$. The AAS data indicated that the Si/Al ratio of the MSA was about 5.65 .

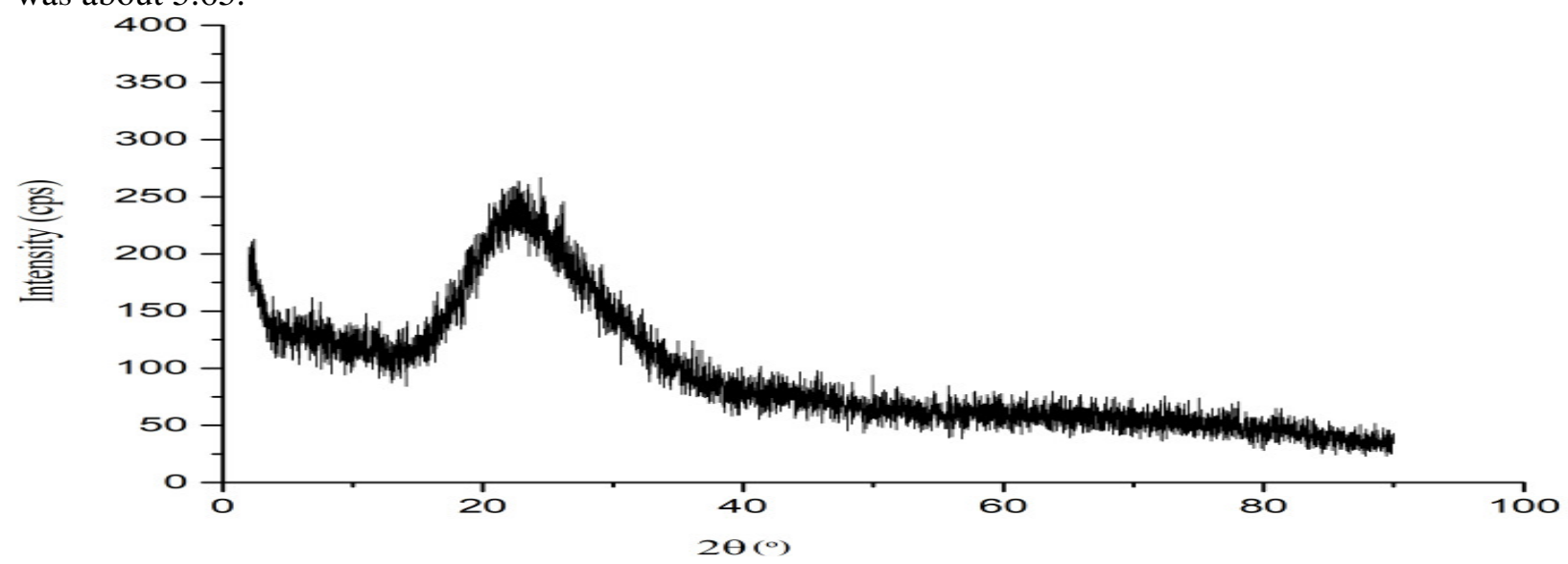

Fig.-3: XRD pattern of the MSA 
Figure-3 presents the XRD pattern of the MSA. The XRD pattern of the MSA has only a single broad peak arising between $2 \theta$ of 20 and $30^{\circ}$, which indicates the MSA as an amorphous material. This result was similar to those shown in the previous studies ${ }^{18,27,30}$. The TEM micrograph of the MSA in Figure-4 shown the presence of particle agglomeration. Furthermore, the pore size of the MSA is not uniform. It was caused by the use of catfish bone gelatin as a mesoporous regulating template agent, which has a wide molecular weight distribution range.
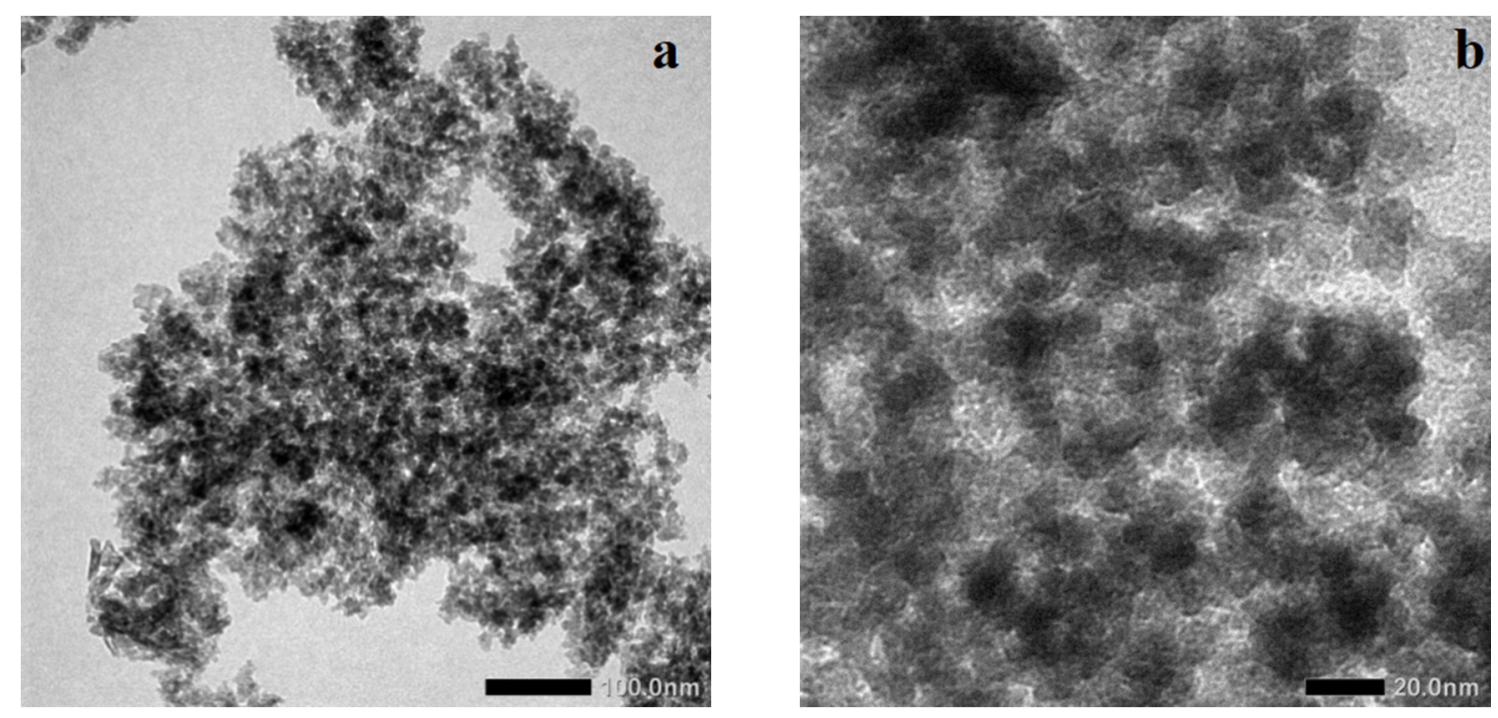

Fig.-4: TEM micrograph of the MSA with micron marker of (a) $100 \mathrm{~nm}$ and (b) $20 \mathrm{~nm}$

\section{Characterization of the Catalysts}

The AAS analysis result of the catalysts is presented in Table-2. The amount of each metal used in the catalysts preparation was about $1.5 \mathrm{wt} . \%$. However, the result shows that both $\mathrm{Ni}$ and Mo metals in the catalysts are less than $1.5 \mathrm{wt} . \%$. This mismatch may be caused mainly by the occurrence of the competition of both $\mathrm{Ni}$ and Mo metals in the pore mouth region. The competition of both Ni and Mo metals can cause the formation of metal multilayers, which have a weak interaction with each metal layer. The metals in this condition are easy to be detached from the MSA pore. It makes the number of active metals located in the pore mouth area is lower than expected ${ }^{31}$.

Table-2: Metal content and acidity of the catalyst

\begin{tabular}{c|c|c|c}
\hline \multirow{2}{*}{ Catalyst } & \multicolumn{2}{|c|}{ Metal content (wt.\%) } & \multirow{2}{*}{$\begin{array}{c}\text { Acidity } \\
\text { (mmol/g) }\end{array}$} \\
\cline { 2 - 3 } & $\mathrm{Ni}$ & $\mathrm{Mo}$ & 13.56 \\
\hline $\mathrm{MSA}$ & 0.00 & 0.00 & 22.08 \\
\hline $\mathrm{Ni} / \mathrm{MSA}$ & 0.93 & 0.00 & 15.16 \\
\hline $\mathrm{Mo} / \mathrm{MSA}$ & 0.00 & 1.14 & 19.60 \\
\hline $\mathrm{NiMo} / \mathrm{MSA}$ & 0.88 & 1.09 & 22.22 \\
\hline $\mathrm{MoNi} / \mathrm{MSA}$ & 0.72 & 0.95 & \\
\hline
\end{tabular}

The loading of Ni and Mo metals on the MSA increased the acidity of the catalysts. The increasing of catalysts acidity after metal loading is due to empty orbitals of the metals ( $4 \mathrm{p}$ at $\mathrm{Ni}$ and $5 \mathrm{p}$ at Mo). The empty orbitals can bind free electron pair as Lewis acid sites ${ }^{10}$. The acidity of Ni/MSA catalyst was higher than the Mo/MSA catalyst. This can be explained by the electron configuration of Ni and Mo metals. The Mo metal has a half-filled orbital $\left(4 d^{5}\right.$ and $\left.5 \mathrm{~s}^{1}\right)$, which gives greater stability to the Mo metal. It means that the $\mathrm{Ni}$ metal is more reactive in accepting the electron pair than the Mo metal. The Mo metals in both NiMo/MSA and MoNi/MSA catalysts was used as a co-promoter. The acidity of the MoNi/MSA catalyst was higher than the NiMo/MSA catalyst. The quality of the catalyst is determined by 
the quality of the metal dispersion in the support materials, while the quality of the metal dispersion in the support materials may be affected by the amount of the metal ${ }^{12}$. The low acidity of NiMo/MSA catalyst may be caused by the dispersion of both Ni and Mo metals, which did not spread evenly in the MSA surface. The amount of Ni and Mo metals loaded on the MSA were high enough to shape aggregates of metal. These aggregates made the active site of the metals to be covered. The MoNi/MSA catalyst had a lower total metals content (1.67 wt.\%) than NiMo/MSA (1.97 wt.\%) catalyst, which makes it too has better metal dispersion.

\section{Catalytic Activity Test}

The activities of Ni/MSA, Mo/MSA, NiMo/MSA, and MoNi/MSA catalysts were evaluated in hydrocracking of pyrolyzed $\alpha$-cellulose. Thermal hydrocracking was performed as a comparator for evaluating of catalysts activity. Table-3 presents products distribution of hydrocracking of pyrolyzed $\alpha$ cellulose. The thermal hydrocracking process produced a lower amount of liquid product than those of the catalytic hydrocracking. These results indicate the presence of catalysts activity in the hydrocracking of pyrolyzed $\alpha$-cellulose. The thermal hydrocracking produced higher gas and residue products than catalytic hydrocracking. It is caused by the differences in the reaction mechanism between the thermal hydrocracking that occurs through the formation of radical ions and the catalytic hydrocracking that occurs through the carbonium ion mechanism. The radical ions formed at the initiation stage of the thermal hydrocracking break the carbon bond at the $\beta$ position and it forms new radical compounds with a smaller number of carbon atoms, thus thermal hydrocracking produced more amount of gas product than catalytic hydrocracking ${ }^{32}$.

Table-3: Products distribution of hydrocracking of pyrolyzed $\alpha$-cellulose

\begin{tabular}{c|c|c|c}
\hline \multirow{2}{*}{ Sample } & \multicolumn{3}{|c}{ Conversion (wt.\%) } \\
\cline { 2 - 4 } & Liquid & Gas & Coke \\
\hline Termal & 72.45 & 27.55 & 0 \\
\hline $\mathrm{Ni} / \mathrm{MSA}$ & 77.33 & 22.66 & 0.02 \\
\hline $\mathrm{Mo} / \mathrm{MSA}$ & 76.67 & 23.47 & 0.04 \\
\hline $\mathrm{NiMo} / \mathrm{MSA}$ & 85.41 & 14.48 & 0.23 \\
\hline $\mathrm{MoNi} / \mathrm{MSA}$ & 85.29 & 14.71 & 0.37 \\
\hline
\end{tabular}

The hydrocracking using NiMo/MSA and MoNi/MSA catalysts produced more amount of liquid product than hydrocracking using the Ni/MSA and Mo/MSA catalysts. These results indicate that bimetal catalyst has greater catalytic activity than monometal catalyst. The Ni and Mo metals in the hydrocracking reaction are used as hydrocracking active sites as the presence of unpaired electrons in their d orbitals. The unpaired electrons in the d orbitals can dissociate hydrogen gas in homolytic, which would be required in the hydrocracking process. The Ni metal ([Ar] $3 d^{8} 4 s^{2}$ ) has two unpaired electrons and the Mo $\left([\mathrm{Kr}] 4 \mathrm{~d}^{5} 5 \mathrm{~s}^{1}\right)$ has five unpaired electrons in their $\mathrm{d}$ orbital. However, the Mo metal is more stable and less reactive in dissociating hydrogen gas than the Ni metal. It is due to the half-filled $\mathrm{d}$ orbital of the Mo metal that has been explained previously. The use of $\mathrm{Ni}$ and Mo metals simultaneously as a bimetal catalyst causes the decreasing of the stability of Mo metal. It means that the Mo metal will be more reactive in dissociating hydrogen gas, if it is used along with the Ni metal.

Table-4. Distribution of compound groups in the liquid product before and after hydrocracking

\begin{tabular}{c|c|c|c|c|c|c}
\hline Functional & \multirow{2}{*}{$\begin{array}{c}\text { Before Hydrocracking } \\
\text { Group }\end{array}$} & \multicolumn{5}{|c}{ After Hydrocracking (wt.\%) } \\
\cline { 3 - 7 } & (wt.\%) & Thermal & Ni/MSA & Mo/MSA & NiMo/MSA & MoNi/MSA \\
\hline Alcohol & 19.08 & 10.00 & 0.00 & 0.78 & 0.00 & 0.00 \\
\hline Ether & 1.28 & 14.39 & 0.00 & 0.00 & 0.00 & 0.00 \\
\hline Aldehyde & 18,67 & 32.61 & 30.41 & 15.29 & 15.85 & 13.68 \\
\hline Ketone & 18.96 & 17.26 & 31.04 & 35.76 & 33.40 & 52.22 \\
\hline
\end{tabular}


RASĀYAN J. Chem.

Vol. 11 | No. 2 |522 - 530 | April - June | 2018

\begin{tabular}{c|c|c|c|c|c|c}
\hline $\begin{array}{c}\text { Carboxylic } \\
\text { acid }\end{array}$ & 9.05 & 0.00 & 30.77 & 25.93 & 42.05 & 27.17 \\
\hline Ester & 3.06 & 0.00 & 0.00 & 10.29 & 0.00 & 0.00 \\
\hline Else $^{\mathrm{a}}$ & 29.9 & 25.75 & 7.78 & 11.97 & 8.71 & 6.93 \\
\hline
\end{tabular}

Note: ${ }^{\text {the }}$ other compound groups

The liquid products obtained from hydrocracking of pyrolyzed $\alpha$-cellulose were a mixture that consists of a large number of compounds representing various chemical species. Table-4 presents the distribution of compound groups in liquid products obtained in this work. Before hydrocracking process, the pyrolyzed $\alpha$-cellulose contains highly varied chemical compounds. After hydrocracking process, the chemical compounds of liquid products become more specific. These results indicate that the catalysts have a selectivity in producing a liquid product. The Ni/MSA, NiMo/MSA and MoNi/MSA catalysts produced a higher amount of chemical compounds with functional groups of aldehydes, ketones, and carboxylic acids.

\section{CONCLUSION}

Catfish bone gelatin can be used as a mesoporous regulating template agent in the synthesis of MSA. The MSA has Si/Al ratio of 5.65, BET specific surface area of $212.29 \mathrm{~m}^{2} / \mathrm{g}$, acidity value of $13.56 \mathrm{mmol} / \mathrm{g}$, BJH desorption pore diameter of $20.05 \mathrm{~nm}$ and pore volume of $1.29 \mathrm{~cm}^{3} / \mathrm{g}$. The NiMo/MSA and MoNi/MSA catalysts have greater catalytic activity than the Ni/MSA and Mo/MSA catalysts in hydrocracking of pyrolyzed $\alpha$-cellulose. The amount of liquid products produced using NiMo/MSA and MoNi/MSA catalyst were 85.51 and $85.29 \mathrm{wt} . \%$, respectively.

\section{ACKNOWLEDGMENT}

The authors thank The Ministry of Research Technology and Higher Education for financial support of this work under the scheme of PUPT 2017 (Contract number: 2454/UN1.P.III/DIT-LIT/LT/2017).

\section{REFERENCES}

1. S. Liu, J. Zhu, M. Chen, W. Xin, Int. J. Hydrogen Energy, 39(15), 13128(2014), DOI: 10.1016/j.ijhydene.2014.06.158.

2. T. Aysu, H. Durak, S. Güner and S. Aydın, Bioresour. Technol., 205, 7(2016), DOI: 10.1016/j.biortech.2016.01.015.

3. D.K. Shen, S. Gu, Bioresour. Technol., 100(24), 6496(2009), DOI: 10.1016/j.biortech.2009.06.095.

4. C. Zhao, E. Jiang, A. Chen, J. Energy Inst., 90(6), 902(2017), DOI: 10.1016/j.joei.2016.08.004.

5. F. Kwaser, G., Nash, J. Oil Palm Res., 12(1), 86(2000).

6. G. Knothe, Biomass and Bioenergy, 58, 143(2013), DOI: 10.1016/j.biombioe.2013.09.003.

7. W. Sriningsih, M.G. Saerodji, W. Trisunaryanti, Triyono, R. Armunanto, I.I. Falah, Procedia Environ. Sci., 20, 215(2014), DOI: 10.1016/j.proenv.2014.03.028.

8. I. Salim, W. Trisunaryanti, Triyono, Y. Arryanto, Int. J. ChemTech Res., 9(4), 492(2016).

9. K. Wijaya, G. Baobalabuana, W. Trisunaryanti, A. Syoufian, Asian J. Chem., 25(16), 8981(2013), DOI: 10.14233/ajchem.2013.14946.

10. M. Pongsendana, W. Trisunaryanti, F.W. Artanti, I.I. Falah, Sutarno, Korean J. Chem. Eng., 34(10), 2591(2017), DOI: 10.1007/s11814-017-0165-3.

11. M. Syamsiro, S. Cheng, W. Hu, H. Saptoadi, N.N. Pratama, W. Trisunaryanti, K. Yoshikawa, Waste Technol., 2(2), 44(2014), DOI: 10.12777/wastech.2.2.44-51.

12. Nurmalasari, W. Trisunaryanti, Sutarno, I.I. Falah, Int. J. ChemTech Res., 9(9), 607(2016).

13. A. Masykuroh, W. Trisunaryanti, I.I. Falah, Sutarno, Int. J. ChemTech Res., 9(9), 598(2016).

14. M. Grilc, B. Likozar, J. Levec, Appl. Catal. B Environ., 150-151, 275(2014), DOI: 10.1016/j.apcatb.2013.12.030.

15. W. Trisunaryanti, Triyono, D. Fibirna, Indones. J. Chem, 3(2), 80(2003), DOI: 10.22146/ijc.21890.

16. S. Indrayanah, A. Rosyidah, H. Setyawati, I.K. Murwani, Rasayan J. Chem., 11(1), 312(2018), DOI: 10.7324/RJC.2018.1111904. 
RASĀYAN J. Chem.

Vol. 11 | No. 2 |522 - 530 | April - June | 2018

17. Y. Xie, D. Kocaefe, C. Chen, Y. Kocaefe, J. Nanomater., 2016, 1(2016), DOI: 10.1155/2016/2302595.

18. H. Setyawan, R. Balgis, Asia-Pasific J. Chem. Eng., 7, 448(2012), DOI: 10.1002/apj.593.

19. W. Trisunaryanti, P.S. Lisna, I. Kartini, Sutarno, I.I. Falah, Triyono, Asian J. Chem., 28(5), 996(2016), DOI: 10.14233/ajchem.2016.19561.

20. H. Chun-Han, L. Hong-Ping, T. Chih-Yuan, L. Ching-Yen, Stud. Surf. Sci. Catal. 165, 385(2007), DOI: 10.1016/S0167-2991(07)80341-7.

21. W. Trisunaryanti, I.I. Falah, M.F. Marsuki, In Proceedings of 15th International Conference on Environmental Science and Technology, Greece, pp. 00741 (2017).

22. J.H. Muyonga, C.G.B. Cole, K.G. Duodu, Food Hydrocoll., 18(4), 581(2004), DOI: 10.1016/j.foodhyd.2003.08.009.

23. M. Ahmad, S. Benjakul, Food Hydrocoll., 25(3), 381(2011), DOI: 10.1016/j.foodhyd.2010.07.004.

24. S. Sinthusamran, S. Benjakul, H. Kishimura, Food Chem., 152, 276(2014), DOI: 10.1016/j.foodchem.2013.11.109.

25. P. Saraswathi, M. Makeswari, Rasayan J. Chem., 10(3), 759(2017), DOI: 10.7324/RJC.2017.1031752.

26. I. Gustian, Ghufira, D. Oktiarni, Rasayan J. Chem., 10(3), 689(2017), DOI: 10.7324/RJC.2017.1031716.

27. B. Xu, Y. Yang, Y. Xu, B. Han, Y. Wang, X. Liu, Z. Yan, Microporous Mesoporous Mater., 238, 84(2017), DOI: $10.1016 /$ j.micromeso.2016.02.031.

28. Sutarno, Y. Arryanto, S. Wigati, Indones. J. Chem, 3(2), 126(2003), DOI: 10.22146/ijc.21896.

29. K.S.W. Sing, D.H. Everett, R.A.W. Haul, L. Moscou, R.A. Pierotti, J. Rouquerol, T. Siemieniewska, Pure Appl. Chem., 57, 603(1985), DOI: 10.1351/pac198557040603.

30. M.R. Agliullin, I.G. Danilova, A.V. Faizullin, S.V. Amarantov, S.V. Bubennov, T.R. Prosochkina, N.G. Grigor'eva, E.A. Paukshtis, B.I. Kutepovad, Microporous Mesoporous Mater., 230, 118(2016), DOI: $10.1016 /$ j.micromeso.2016.05.007.

31. C.H. Bartholomew, R.J. Farrauto, Fundamentals of Industrial Catalytic Processes, John Wiley \& Sons, New Jersey, p.99(2006), DOI: 10.1002/9780471730071.

32. T.S. Sie, Ind. Eng. Chem. Res., 31(8), 1881(1992), DOI: 10.1021/ie00008a008.

[RJC-2061/2018] 